\title{
BRAZILIAN LITERARY CRITICISM AND HISTORIOGRAPHY
}

\section{CRÍTICA E HISTORIOGRAFIA LITERÁRIA BRASILEIRAS}

\begin{abstract}
Roberto Acízelo de Souza ${ }^{1}$
José Luís Jobim²

Resumo: Os estudos literários brasileiros, depois de manifestações esparsas no período colonial, representadas pela atividade de academias literárias fundadas no século XVIII, só se expandiram efetivamente ao longo do século XIX. A produção literária nacional cresceu em quantidade e qualidade, assim como os estudos literários, que, por um lado, eram demandados por esta produção - a qual, afinal de contas, necessitava ser estudada e avaliada -, mas, por outro lado, estimulavam esta criatividade, ao estabelecerem como critério de valor o alinhamento da ficção, poesia e dramaturgia com a agenda nacionalista. Como resultado, de 1820 a 1880, os estudos literários no Brasil passaram por um período de expansão e diversificação. Se nos anos 1800 a educação literária foi conduzida no ensino de segundo grau, de 1930 em diante cursos de literatura em nível universitário começaram a estabelecer-se no Brasil. Neste artigo, faremos uma breve introdução à crítica e à historiografia literária brasileira, desde seus primórdios até o presente.
\end{abstract}

Palavras-chave: crítica literária brasileira, historiografia literária brasileira

\begin{abstract}
In Brazil literary studies, after scant manifestations in the colonial period, represented by the activity of literary academies founded in the 18th century only really expanded in the course of the 19th century. National literary production grew in quantity and quality, as did literary studies, which, on the one hand, were demanded by this production - that, after all, needed to be studied and evaluated - , but, on other hand, stimulated this creativity, as they established as a criterion of value the alignment of fiction, poetry and dramaturgy with the nationalist agenda. As a result, from the $1820 \mathrm{~s}$ until the 1880s, literary studies in Brazil underwent a period of expansion and diversification. If in the 1800s literary education was conducted at high-school level, from the 1930s onwards university courses in literatures began to be established in Brazil. In this paper we will provide a short introduction to Brazilian literary criticism and historiography from its very beginnings to the present time.
\end{abstract}

Keywords: Brazilian literary criticism, Brazilian Literary historiography

In Brazil literary studies, after scant manifestations in the colonial period, represented by the activity of literary academies founded in the 18th century, short texts by a handful of poets - Cláudio Manuel da Costa (1729-1789), Basílio da Gama (1741-1795) and Silva Alvarenga (17490-1814) - and the teaching of the humanities in schools (all of which were supported by Catholic religious orders), only really expanded in the course of the 19th century.

\footnotetext{
${ }^{1}$ Universidade do Estado do Rio de Janeiro - UERJ, Rio de Janeiro, Rio de Janeiro, Brasil; https://orcid.org/0000-0003-0607-5911; acizelo@bighost.com.br

${ }^{2}$ Universidade Federal Fluminense - UFF, Niterói, Rio de Janeiro, Brasil; https://orcid.org/0000-0002-02716665; jjobim@id.uff.br
}

Rev. Bras. Lit. Comp. Niterói, v. 22, n. 41, pp. 37-45, set. /dez. 2020 
Two political events in particular, which had cultural consequences, contributed to this expansion: the transfer of the Portuguese monarchy to Rio de Janeiro (1808) and the proclamation of Brazilian Independence (1822). From then on, at an increasingly rapid pace, efforts to consolidate a distinct physiognomy for Brazil within the "concert of civilised nations" (a phrase used at the time) led to, among many other political, economic and cultural consequences, the concept of an aesthetic-political project rooted in Romanticism and dedicated to the creation of a distinctly Brazilian literature, which, as such, would provide a portrait of the entire nation, representing its natural environment, history and society. In this way, national literary production grew in quantity and quality, as did literary studies, which, on the one hand, were demanded by this production - that, after all, needed to be studied and evaluated -, but, on other hand, stimulated this creativity, as they established as a criterion of value the alignment of fiction, poetry and dramaturgy with the nationalist agenda. As a result, from the 1820 s until the 1880s, literary studies in Brazil underwent a period of expansion and diversification.

In the field of education, a conservative stance remained, continuing the humanistic tradition of the colonial schooling system, basing literary education on the ancient classical disciplines of rhetoric and poetics. This situation would only begin to change around the $1870 \mathrm{~s}$, when these disciplines were replaced by a modern discipline that was introduced to curricula: history of literature, particularly Brazilian literature. The need to provide materials for use in schools led to the production of compendiums and manuals of rhetoric and poetics, general survey works with a strictly didactic purpose, that followed classical concepts but were sometimes nuanced by traces of Romanticism, an influence that was virtually unavoidable in the era in which they were produced. Examples of this type of work include, amongst many others, Lições de eloquência nacional (Lessons in National Eloquence, 1846), by Lopes Gama (1793-1852), Elementos de retórica nacional (Elements of National Rhetoric, 1869), by Junqueira Freire (1832-1855), Postilas de retórica e poética (Lesson Guides in Rhetoric and Poetics, 1872), by Fernandes Pinheiro (1825-1876), Compêndio de retorica e poética (Compendium of Rhetoric and Poetics, 1879), by Costa Honorato (1838-1891), and Lições de retórica (Lessons in Rhetoric, 1882), by Velho da Silva (1811-1901).

In the field of criticism, understood as the analytical study of specific literary works, there was a proliferation of essays, sometimes about works from the past, but chiefly about what were then recent publications, generally published in eclectic periodicals, including Niterói (1836), Jornal de Debates Políticos e Literários (1837-1838), Minerva Brasiliense (1843-1845), O Guanabara (1849-1855), Revista Popular (1850-1869), and A Atualidade (1859-1864). Within this category, a few names stand out, such as those of Dutra e Melo (18231846), Machado de Assis (1839-1908), Macedo Soares (1838-1905), and Araripe Júnior (18481911).

Although rare, there were also examples of what we could term meta-criticism, in texts, for example, by Machado de Assis and Macedo Soares, as well as critical works written by poets and writers of fiction, which focused on reflections on their own personal literary projects or on evaluations of the work of others. Notable examples of this type of writing include those of José de Alencar (1829-1877) and Álvares de Azevedo (1831-1852).

As regards studies of a historiographic nature, this period witnessed the development of various genres. One of these was anthologies or compilations, the underlying purpose of which, as defined a few short years after Independence, was to collate the work of poets, especially from the colonial period, with the stated aim of making Brazilians themselves aware of the nation's poetic traditions, the quality of which, according to the anthologists, spoke volumes for national greatness. This trend began with Parnaso brasileiro (Brazilian Parnassus, 18291832), by Januário da Cunha Barbosa (1780-1846), which was followed by another two works with the same title, the first published in 1843 and the second in 1885 , edited respectively by Pereira da Silva (1817-1898) and Melo Morais Filho (1844-1919). The other most notable 
publications of this kind include Mosaico poético (Poetic Mosaic, 1844), by Joaquim Norberto (1820-1891) and Emílio Adet (1818-1867), and the Florilégio da poesia brasileira (Anthology of Brazilian Poetry, 1850-1853), by Francisco Adolfo de Varnhagen (1816-1878).

There were also publications that brought together the biographies of writers, such as Plutarco brasileiro (Brazilian Plutarch, 1847) and Varões ilustres do Brasil nos tempos coloniais (Illustrious Gentlemen of Colonial Brazil, 1858), by Pereira da Silva, as well as Panteon maranhense (Pantheon of the Province of Maranhão, 1873-1875), by Antônio Henriques Leal (1828-1885), and the Dicionário bibliográfico brasileiro (Brazilian Bibliographical Dictionary, 1883-1902), by Sacramento Blake (1827-1903).

In the field of literary historiography, there were also statements of intent that aimed to establish an authentically Brazilian literature, written in the form of manifestos that, undertaking an evaluation of writing from colonial times, urged contemporary writers to deepen the national traits that supposedly already existed in embryonic form back in those earlier centuries. In a similar vein to these essays are the historical overviews of Brazilian literature that, providing inventories of the past, also make projections about the auspicious future of national letters by fully embracing what was then referred to as national character. Examples of the first category include "Resumo da história literária do Brasil" (Summary of the Literary History of Brazil, 1826), by Ferdinand Denis (1798-1890), "Ensaio sobre a história da literatura brasileira" (Essay on the History of Brazilian Literature, 1836), by Gonçalves de Magalhães (1811-1882), and "Da nacionalidade da literatura brasileira" (On the Nationality of Brazilian Literature, 1843), by Santiago Nunes Ribeiro (circa 1820-1847); and examples of the second trend include "Bosquejo da história da poesia brasileira" ("Sketch of the History of Brazilian Poetry", 1841), by Joaquim Norberto, and "Formação da literatura brasileira" (Formation of Brazilian Literature, 1862), by Fernandes Pinheiro.

We should also mention the important strand of historiographic research involved in the preparation of editions, notably by Joaquim Norberto, whose work that focused on establishing the texts of poets gave rise to carefully edited, amply annotated books and critical-biographical studies, devoted to the works of Gonzaga (1744-1810), Silva Alvarenga (1749-1814), Alvarenga Peixoto (1742-1793), Gonçalves Dias (1823-1864), Álvares de Azevedo (18311852), Casimiro de Abreu (1839-1860) and Laurindo Rabelo (1826-1864), volumes that were published respectively in 1862, 1864, 1865, 1870, 1873, 1876 and 1877.

Finally, still within the field of historiography, we should highlight the publication of histories of Brazilian literature, some of which had a stated didactic purpose whereas others were more essayistic in nature. All, however, were to play a decisive role in the institutionalisation of an idea of Brazilian literature, given their place within the national education system. A pioneering work of this kind was História da literatura brasileira (History of Brazilian Literature) by Joaquim Norberto, which, however, was incomplete and patchy, since its author abandoned the project, not managing to collate in a single volume the chapters that he had published in the periodical Revista Popular between 1859 and 1862. This was followed by the Curso elementar de literatura nacional (Elementary Course in National Literature, 1862), by Fernandes Pinheiro, O Brasil literário (Literary Brazil, 1863), by Ferdinand Wolf (1796-1866), the Curso de literatura portuguesa e brasileira (Portuguese and Brazilian Literature Course, 1866-1873), by Sotero dos Reis (1800-1871), and, finally, representing the pinnacle of this genre in the $19^{\text {th }}$ century, the Historia da literatura brasileira (History of Brazilian Literature, 1888), by Sílvio Romero (1851-1914), a work that, due to the prestige it would go on to garner, represents a landmark in the process of the consolidation of Brazilian literature - and its history - as academic disciplines and national institutions.

In general, the literary studies scene in $19^{\text {th }}$-century Brazil was powerfully shaped by a Romanticist and nationalist perspective, which was, furthermore, in harmony with the historical process of consolidating Brazil's Independence. Even on a more conservative level, represented 
by the education system, in which, as we have seen, a universalist outlook based on classical values predominated, nationalism still left its mark, whether in the presence of the symptomatic adjective national in the titles of didactic manuals - see the aforementioned Lições de eloquência nacional (Lessons in National Eloquence) and Elementos de retórica nacional (Elements of National Rhetoric, 1869) -, or in the introduction, from the 1870s onwards, of the discipline history of Brazilian literature in school curricula, accompanied by the corresponding removal of rhetoric and poetics. Nevertheless, there were a small number of voices that sang from a different hymn sheet, such as Abreu e Lima (1794-1869), in the forgotten volume entitled Bosquejo histórico, político e literário do Brasil (Historical, Political and Literary Sketch of Brazil, 1839), Álvares de Azevedo, in his lengthy and also forgotten study "Literatura e civilização em Portugal" (Literature and Civilisation in Portugal), written in around 1850, but published posthumously, and Machado de Assis, in his famous essay "Notícia da atual literatura brasileira: instinto de nacionalidade" (Reflections on Brazilian Literature at the Present Moment - the National Instinct), published in 1873.

Finally, we should point out that these publications were very unevenly distributed across the territory of Brazil, and were densely concentrated in Rio de Janeiro, capital of the Empire and later the Republic, and from there were disseminated to the other regions of the country. Consequently, literary studies flourished in few other major cities, and generally any such activity failed to make an impact on a national scale. In the north, significant examples of literary criticism appeared in São Luís, in the Province of Maranhão, and Recife, in the Province of Pernambuco, and in the south, in Porto Alegre, in the Province of Rio Grande do Sul. One of the most important literary critics of the $19^{\text {th }}$ century, the aforementioned Sílvio Romero, born in the Province of Sergipe (far away from Rio de Janeiro and these other urban centres), described the situation as follows: "The function of the provinces [...], of the north, south, centre and west, is to produce variety within unity and supply the Capital with their greatest talents" (Romero, 1907).

This situation persisted into the $20^{\text {th }}$ century, even becoming more acute, with the concentration of literary studies being produced in the Rio de Janeiro/São Paulo axis. More recently, in spite of better distribution, with the expansion of university courses in languages and literatures - particularly at postgraduate level - in all states, a large concentration of literary criticism is still produced in the south-east and south regions, which are home to the oldest and most established university courses.

What follows is an overview of the state of affairs in the $20^{\text {th }}$ century, in all its different aspects, beginning with the question of education.

If in the 1800s literary education was conducted at high-school level, from the 1930s onwards university courses in literatures began to be established in Brazil. Until around the 1960s, there were only undergraduate courses, and the historicist viewpoint completely dominated, with the great treatises on the history of Brazilian literature fulfilling a central role as bibliographical support. As discussed above, the high prestige of these works had been established in the $19^{\text {th }}$ century, with the aforementioned Historia da literatura brasileira (History of Brazilian Literature) by Sílvio Romero. The theoretical dimension of literary studies remained virtually unexplored, which explains the lack of published work to support it. The few theoretical works that emerged, moreover, were anachronistic rhetoric manuals, almost entirely alien to the new perspectives now defined in this field. This is the case of works like Noções de estilística e literatura (Notions of Stylistics and Literature, 1929), by Antenor Nascentes (1886-1972), Teoria da literatura (Theory of Literature, 1935), by Estêvão Cruz 
(1902-1937), Princípios elementares de literatura (Elementary Principles of Literature, 1935), by Augusto Magne (1887-1966), Teoria da literatura (Theory of Literature, 1944), by Antônio Soares Amora (1917-1999), and Teoria literária (Literary Theory, 1965), by Hênio Tavares.

From the 1970s onwards, postgraduate courses were established - Masters and doctoral programmes -, and correspondingly, in line with the major universities of Europe and North America, the theoretical component of literary studies was strengthened. Academic manuals were published that aimed to support the teaching of the new discipline introduced into Brazilian university curricula in the early 1960s- the theory of literature -, a subject that experienced a dramatic growth and in a short space of time began to overshadow the traditional disciplines of literary history in Brazilian arts faculties, namely Brazilian literature and Portuguese literature. As well as much used foreign manuals, like Teoria da literatura (Theory of Literature, 1949), by René Wellek (1903-1995) and Austin Warren (1899-1986), and the identically titled book by the Portuguese professor Vítor Manuel de Aguiar e Silva, published in 1967, the most acclaimed Brazilian book on this subject was A criação literária (Literary Creativity, 1965), by Massaud Moisés (1928-2018).

This sums up university education between 1930 and 1980, more or less, which was characterised initially by the absolute predominance of the history of literature, then by the rise of the theory of literature, until that discipline acquired a prime position within curricula, with both supported by bibliographical materials that for the most part consisted of great treatises on literary history and manuals on the theory of literature. This situation would be profoundly altered from the final decade of the $20^{\text {th }}$ century onwards. At that time, after the historicist perspective had fallen out of favour, the theory of literature followed suit, and the text books that represented the mainstay of students' education were virtually decommissioned and replaced by heterogeneous and piecemeal bibliographical materials, basically composed of timely studies about contemporary topics, frequently in the form of articles, disseminated via specialised academic journals, or chapters in co-authored books.

Anthologies, in turn, continued to be published. Their function, however, in relation to their underlying objective in the $19^{\text {th }}$ century - to show Brazilians themselves that their country had produced high-quality poetry since colonial times -, changed. They became didactic tools, initially designed to support the teaching of the Portuguese language and Brazilian literature at high-school level. The most famous of these - Antologia nacional (National Anthology), by Fausto Barreto (1852-1908) and Carlos de Laet (1847-1927) - represented a kind of link between the $19^{\text {th }}$ and $20^{\text {th }}$ centuries since, first appearing in 1895, it was published in forty-three different editions, the last of which appeared in 1969. Other anthologies, however, especially of poetry, aimed either to promote the work of poets - as was the case of those edited by Manuel Bandeira (1886-1968), with the collaboration of Walmir Ayala (1933-1991): Apresentação da poesia brasileira (Presentation of Brazilian Poetry, 1946) and Antologia de poetas brasileiros (Anthology of Brazilian Poets), from the colonial era (1967), the Romantic era (1937), the Parnassian era (1940), the Symbolist era (1967) and the Modern era (1967) -, or to support the teaching of literature at university level. The latter category of publications included Presença da literatura portuguesa (Presence of Portuguese Literature, 1961), edited by Antônio Soares Amora, with the collaboration of Segismundo Spina (1921-2012) and Massaud Moisés, and Presença da literatura brasileira (Presence of Brazilian Literature, 1964), by Antônio Candido (1918-2017) and José Aderaldo Castello (1921-2011).

The production of meticulous editions, another aspect of Brazilian literary culture that began promisingly in the $19^{\text {th }}$ century - especially, as stated above, thanks to Joaquim Norberto - , left a lot to be desired in the $20^{\text {th }}$ century, and to the present day there have been no signs that this scenario has altered much in the $21^{\text {st }}$. Consequently, even fundamental works like, amongst many others, those of Machado de Assis, are still awaiting a higher-quality editorial treatment. 
Literary criticism in the strict sense of the term, i.e. the appreciation of specific literary works - especially recently published ones -, aimed at providing judgements of aesthetic value, has continued on its path, making use in particular, as was the case in the $19^{\text {th }}$ century too, of newspapers, a medium that fits its objective, which is to promote literary production to a heterogenous, non-specialist public. In the first decades of the $20^{\text {th }}$ century, literary criticism occupied a generous amount of column inches in newspapers, and there was no shortage of people who earned the reputation of being great critics, due to their regular publication of articles, like, for example, João Ribeiro (1860-1934), Medeiros e Albuquerque (1867-1934), Agripino Grieco (1888-1973), Alceu Amoroso Lima (1893-1983), Humberto de Campos (1886-1934), Álvaro Lins (1912-1970), and Wilson Martins (1921-2010), who generally later collated their newspaper writings in book form. Wilson Martins explained this practice as follows:

Literary criticism has a commitment to the present day and the ambition of permanence: that is why critics periodically bring together their works in volumes, like virtual chapters of the future history of literature, for which, in the language of the goldsmith, they serve as contrast, that is to say, as an index of evaluation (Martins, 2005).

This type of criticism, impressionistic in nature - i.e. limited to the exposition of critics' impressions about their readings, without any engagement with theories or methods -, started to lose ground and influence around the 1960s, for at least two connected reasons.

On the one hand, the modernisation of the daily press, increasingly characterised by objectivity, a light touch and synthesis, has led to alterations in the traditional layout of print newspapers themselves, reducing the space on the page, which has led to the gradual shrinkage of column inches dedicated to criticism in daily newspapers. Such columns have virtually disappeared, alongside the progressive extinction of so-called literary supplements (sections of newspapers specialised in literature, that generally accompany the Saturday or Sunday editions of the major newspapers). However, it is important to point out that this reduction or elimination of column inches dedicated to literary criticism has not only occurred in relation to this type of criticism, but also to other kinds (theatre, visual arts and cinema reviews etc.). This has coincided with a general decline in print media as a whole, which has seen the disappearance of traditional publications, the appearance of new ones and the overall reformatting of their presentation and purposes, as they also compete with publications distributed free of charge in metro stations, shops, hotels and so on, in Brazil's big cities - publications that are entirely funded by advertisers. Within this media model, if neither the coverage of facts of relevance to the majority of the population earns column inches for more in-depth analysis, there is no hope of special attention being given to criticism.

On the other hand, in Brazil the creation of higher education courses in literatures has established conditions for the development of what has been called - rather inappropriately university criticism. A more fitting name would be literary studies, since such courses are actually an amalgamation of disciplines that, beyond critical practices in the strict sense of the term, also include literary history and theory.

This university criticism, in the 1950s, seeking to take a polemical stance, tried to differentiate itself from what had come to be known pejoratively as footnote criticism (because originally such criticism appeared as articles at the bottom of the pages of print newspapers, hence 'footnotes'), journalistic criticism or impressionistic criticism. Two kinds of criticism therefore emerged: one produced by educated non-specialist readers, writing in the press, and the other produced by specialist academics who teach on related university degree programmes. The former, aimed at the so-called general public that reads print newspapers, has gradually 
lost column inches and prestige, as discussed above, and today is virtually non-existent; the latter, which circulates through academic circles, and was initially motivated by the establishment of arts faculties in Brazil, has been thriving since at least the 1970s at institutional level, benefitting from the creation of post-graduate courses in this area.

The history of literature, in turn, has remained as active as it was in the $19^{\text {th }}$ century.

Universities have consolidated Brazilian literature and Portuguese literature historicised conceptual constructs, as we know, like the other disciplines configured as national literatures -, which attained the undeniable status of principal literary disciplines, both at highschool and university level, a situation that would only begin to change in the 1960s, when the theory of literature was included with these disciplines, and later, since the year 2000, more or less, with Portuguese literature experiencing a certain loss of prestige.

As regards publications, important essays have appeared that focus on defining the concept of Brazilian literature, as well as seeking to propose appropriate categories and methods for the historiographic study of works that compose this field. Examples of this kind of essay include: Uma interpretação da literatura brasileira (An Interpretation of Brazilian Literature, 1943), by Vianna Moog (1906-1988); Introdução à literatura brasileira (Introduction to Brazilian Literature, 1956), by Alceu Amoroso Lima; and Conceito de literatura brasileira (The Concept of Brazilian Literature, 1960), by Afrânio Coutinho (1911-2000). However, Formação da literatura brasileira (Formation of Brazilian Literature, 1957), by Antônio Cândido, is undoubtedly the most influential of such studies, and despite only dealing with two historical periods - Arcadism and Romanticism -, is seen as an overarching history of literary culture in Brazil.

There were, however, no shortage of works written with this same aim in mind, works which over the course of the $20^{\text {th }}$ century maintained the tradition established in the $19^{\text {th }}$ century, whose crowning moment, as stated above, was the publication of Sílvio Romero's História da literatura brasileira (History of Brazilian Literature). Some of these titles remained very faithful to the $19^{\text {th }}$-century generic model, like História da literatura brasileira (History of Brazilian Literature) by José Veríssimo, published in 1916, and Pequena história da literatura brasileira (Short History of Brazilian Literature) by Ronald de Carvalho (1893-1935), dated 1919. Other projects, however, proposed re-conceptualisations of the historiography of Brazilian letters, based on new, diverse principles. This category includes: História da literatura brasileira (History of Brazilian Literature, 1938), by Nélson Werneck Sodré (19111999); A literatura no Brasil 1968-1971 (Literature in Brazil, 1968-1971), a multi-authored volume edited by Afrânio Coutinho; the six-volume series "A literatura brasileira" (Brazilian Literature), part of the collection "Roteiros das grandes literaturas" (Itinerary of Major Literatures) - Manifestações literárias da era colonial (Literary Manifestations of the Colonial Era, 1962), by José Aderaldo Castello; O romantismo (Romanticism, 1967), by Antônio Soares Amora; O realismo (Realism, 1963), by João Pacheco (1919-1966); O simbolismo (Symbolism, 1966), by Massaud Moisés; O pré-modernismo (Pre-Modernism, 1966), by Alfredo Bosi; $O$ modernismo (Modernism, 1965), by Wilson Martins (1921-2010); História concisa da literatura brasileira (Concise History of Brazilian Literature, 1970), by Alfredo Bosi; De Anchieta a Euclides (From Anchieta to Euclides, 1977), by José Guilherme Merquior (19411991); História da literatura brasileira (History of Brazilian Literature, 1983-1989), by Massaud Moisés; and A literatura brasileira: origens e unidade (Brazilian Literature: Origins and Unity, 1999), by José Aderaldo Castello (1921-2011).

Nevertheless, the great treatises on the history of Brazilian literature that have constituted, as discussed above, not only an academic genre but also a national institution - as they have defined the mandatory material taught in high schools and at universities -, were already looking worn out in around the 1970s. Thus, the História da literatura brasileira (History of Brazilian Literature) by Massaud Moisés, published a hundred years after Sílvio 
Romero's landmark book with the same title, seems to have been one of the last examples of this tradition. Although since then publications have appeared that take a historical approach to Brazilian literature, there are no signs that this 'institutionalised genre' will be revitalised in the present day, at least not in the form it took in the past.

This fact, however, represents just one aspect of the wider shift within literary studies in Brazil, a shift that has been observable since the end of the last century and has more clearly manifested itself in the first two decades of the $21^{\text {st }}$ century.

Literary criticism that circulated in the print editions of the major newspapers, as we have seen, has practically disappeared, but still survives in the digital versions of these publications. Alternatively, criticism in a digital format, in diverse forms (magazines, periodicals, websites, blogs, etc.), is now increasingly prevalent.

The traditional elements of so-called university criticism have, in turn, been significantly altered. Among the disciplines mapped on to national literatures, Brazilian literature has retained its lead position, whereas Portuguese literature has declined significantly, and Lusophone African literatures are on the rise, although their status within the curriculum is still incipient at university level. The same is true of comparative literature, which is primarily taught at post-graduate level. Unlike in previous times, the literary works that constitute these literary disciplines are no longer treated just as components of a system that aims to assert national character, or as rich, self-referential written artefacts. They are also frequently studied in relation to other discursive material - not necessarily of a literary nature -, and this shift in approach reveals a change in conceptual paradigms: instead of principles provided by literary history and theory, the point of reference is now an expanded idea of literature, which embraces previously excluded elements. As a result, literature is losing the features that, from a $19^{\text {th }}$ - and $20^{\text {th }}$-century perspective, endowed it with a particular, distinctive quality.

This state of affairs appears to be increasingly institutionalised, often presenting itself as coherent with emancipatory social movements, such as feminism and the struggles of minority ethnic groups. As evidence of this one only has to consider the reforms taking place in undergraduate curricula in Brazil, supported by federal legislation, which aim to bring literature degree courses in line with these new agendas, as well as to expand and consolidate the various postgraduate programmes in literary studies.

Such an expanded notion of literature, for better or for worse, has also been discussed by professional academic associations, such as the Associação Nacional de Pós-Graduação e Pesquisa em Letras e Linguística (National Association of Postgraduate Studies and Research in Languages, Literatures and Linguistics, ANPOLL) - and the Associação Brasileira de Literatura Comparada (Brazilian Comparative Literature Association, ABRALIC) -, established in 1984 and 1986 respectively.

An evaluation of this scenario entails at least two aspects. On the one hand, the historical relevance of all these discussions is undeniable, since neither literary criticism can be entirely separated from the complex situations in which it is produced and used, nor is the literary critic an isolated thinker, cut off from the rest of the world. In fact, both are rooted in historical communities, in which the world is always endowed with many previously articulated meanings that maintain socially constructed relationships. On the other hand, there is also a risk, namely that literary studies will lose their specificity entirely, be diluted into aspects and methods of other fields of knowledge, and thus be deprived of the conditions to legitimise themselves, both on an epistemological and political-academic level. 


\section{WORKS CITED:}

AZEVEDO, Álvares de. Literatura e civilização em Portugal. Edição de Roberto Acízelo de Souza. Rio de Janeiro: Caetés, 2016.

https://www.eduerj.com/eng/?product=literatura-e-civilizacao-em-portugal

PINHEIRO, Joaquim Caetano Fernandes. Historiografia da literatura brasileira: textos inaugurais. Organização de Roberto Acízelo de Souza. Rio de Janeiro: Eduerj, 2007.

REIS, Francisco Sotero dos. Curso de literatura portuguesa e brasileira: fundamentos teóricos e autores brasileiras. Organização de Roberto Acízelo de Souza. Rio de Janeiro: Caetés, 2014.

SOUZA, Roberto Acízelo de (Org.). Historiografia da literatura brasileira: textos fundadores (1825-1888). Rio de Janeiro: Caetés, 2014. 2 v.

(Org.). Na aurora da literatura brasileira: olhares portugueses e estrangeiros sobre o cânone nacional em formação - 1805-1885. Rio de Janeiro: Caetés, 2017.

https://www.eduerj.com/eng/?product=na-aurora-da-literatura-brasileira

MARTINS, Wilson. Sobre a crítica. Originally published at JBonline, 03/09/2005. Available at < http://www.jornaldepoesia.jor.br/wilsonmartins107.html> Accessed on: 10 April 2020.

ROMERO, Sílvio. João do Rio entrevista Sílvio Romero [1907]. Bula Revista. Available at: http://acervo.revistabula.com/posts/entrevistas/joao-do-rio-entrevista-silvio-romero Accessed on: 10 April 2020.

Roberto Acízelo de Souza é Professor Titular da Universidade do Estado do Rio de JaneiroUERJ, pesquisador do CNPq e Cientista do Nosso Estado (FAPERJ). Mais informações em http://lattes.cnpq.br/4158681002482304

José Luís Jobim é Professor Titular da Universidade Federal Fluminense- UFF, pesquisador do $\mathrm{CNPq}$ e Cientista do Nosso Estado (FAPERJ). Mais informações em http://lattes.cnpq.br/2864489503546804

\section{Declaração de autoria e responsabilidade pelo conteúdo publicado}

Os autores declaram que a elaboração do artigo, em todas as suas etapas e partes, foi um trabalho conjunto.

Submetido em 21/04/2020

Aprovado em 23/06/2020 